cannot expect in four years to reach the position which it has taken forty years of organisation, skill, and enterprise on the part of Germany to secure.

The country, therefore, will welcome the steps which the Board of Trade has taken, in conformity with the Prime Minister's recent statement in Parliament, to protect goods manufactured in Great Britain and Ireland against "dumping," and to check any flood of imports (for instance, from Germany) that might arise from a collapse of exchange so disproportionate to costs of production in the country of origin as to enable sales to take place in this country at prices altogether below costs of production here. It is, of course, too much to expect that this action will pass unchallenged. There is a school of politicians in this country who, like the Bourbons, learn nothing and forget nothing. They are a decreasing faction, it is true, and recent events have tended to submerge the survivors. In a few years they will be as extinct as the dodo. It is a significant fact that the fiscal tenets of the Manchester School are never cherished by a real democracy.

Pending the legislation which is to be introduced into Parliament when it reassembles in the autumn, the Board of Trade under the powers conferred upon it will, as from September I, 1919, prohibit the importation into the United Kingdom of synthetic dyestuffs, drugs, and "intermediates" needed in their manufacture; also synthetic flavourings and perfumes, synthetic photographic chemicals, and a considerable number of inorganic products and medicaments of which the manufacture had to be started in this country in consequence of the war, and which German manufacturers had intended to "dump" into this country as soon as trade relations were re-established.

In addition to the chemical products enumerated in the schedule of the proclamation, the Board of Trade is taking steps to protect the new industries dealing with optical glass, scientific glassware, laboratory porcelain, and a number of products of which the Germans by various means, some of them of a very dubious character, had secured a monopoly. This action will, no doubt, occasion great perturbation in the Teutonic mind. It may even amount to dismay. The enemy had probably calculated, and as usual miscalculated, on prejudices which occasionally seem to obscure the recognition of our true interests as a trading community. "'Tis sport to have the engineer hoist with his own petar."

\section{THE ORGANISATION OF RESEARCH.}

PART of the scheme devised by the Department of Scientific and Industrial Research for the administration of the funds placed at its disposal by Parliament was the formation of associations among groups of manufacturers, and a conference was held on July 29 of representaNO. 2601 , VOL. IO4] tives of the associations already formed for the purpose of discussing some of the many problems which have presented themselves in connection with their work.

In the absence of Mr. H. A. L. Fisher, President of the Board of Education, the chair was taken by Sir William McCormick, chairman of the Advisory Council. Sir Frank Heath, secretary of the Department of Scientific and Industrial Research, was also present, besides some sixty to seventy representatives. A great diversity of subjects was thus represented, though some, especially the great chemical industries, were conspicuously unrepresented.

The meeting was informed that nine research associations were in operation, eight more have been approved and are only waiting the licence of the Board of Trade, while twelve others are under discussion. So much having been accomplished in the three years which have elapsed since the idea originated, it may be assumed that a general approval has been given to the scheme by the industrial world, but the initial difficulties are far from being overcome as yet.

Among the subjects discussed at the conference the first was the formation of a records bureau, and the second the difficult and important one of the conditions of employment of research workers engaged by the associations. Other questions related to co-operation among the associations, and the amount and method of assessment of the subscriptions to be paid by. the associated firms in addition to the subsidy from departmental funds.

The formation of a bureau of information and for the recording of results secured by research is a matter of the utmost importance. In the first place it is proposed that its task should consist in storing up the results of work done by the associations, but even this will be found very expensive and not free from difficulties, owing to the views prevalent in some quarters as to secrecy. The associations require access to information of every kind, and apparently the representatives assembled have something to learn with regard to the existing sources of much of the information they require, for throughout the discussion no reference was made to the magnificent journals, containing both original papers and abstracts, issued by some of the British and American engineering and chemical societies. It seems to be recognised that a large number of reference libraries will have to be established, especially in the neighbourhood of great centres of industry; but it ought also to be understood that every association will require a library stored with works of reference, and especially journals cognisant of the subjects it represents; indeed, every works which has a laboratory for research must be similarly provided. All this represents a large outlay of money, the amount of which can scarcely be calculated as yet.

The other serious point under discussion concerned the interests of the separate associations, and perhaps more particularly those of the in 
dividual research workers. And here it would be well to consider the difference between discovery and invention. The former is usually the result of protracted inquiry by highly skilled and highly educated workers, while invention may, and does often, result from the recognition of a need or opportunity for improvement in a machine or process by a mere workman, ignorant of science in a general sense, but whom long experience in some one industry has led to realise the technical difficulties peculiar to the work in which he has been engaged. The question before the conference was how to estimate the value of the services rendered by a successful employee and the right way to reward them. This is a very difficult problem. Any system of bonuses would be for various reasons undesirable and perhaps unfair. There was agreement that the scale of remuneration must be liberal, in order, for one thing, that the man so employed may be free from anxieties as to his own future. But it is becoming clear to everyone that if industry is to enjoy the advantage of engaging the best brains of the nation this kind of calling must be made attractive to the rising young $m \in n$ and women. At present, as pointed out by the chairman, the new research associations are finding that there are not sufficient scientific workers to go round.

\section{THE BOURNEMOUTH MEETING OF THE BRITISH ASSOCIATION.} $\mathrm{HE}$ success of the meeting of the British
Association, which opens in Bournemouth on September 9, should be a foregone conclusion if one may judge by its appeal to the imagination. It may be said that a scientific history of the war will be presented. Commencing with the inaugural address of the president (the Hon. Sir Charles A. Parsons, K.C.B.), which will deal with "Engineering and the War," throughout the week the invaluable war-work of men of science, which played so magnificent a part in our victory, will be the subject of a great variety of lectures and debates. Secrets which have hitherto been jealously preserved will be made public, and it should be possible after the meeting to estimate as never before the enormous importance of science in modern military operations.

Apart from questions of war, a large proportion of the papers and discussions will be closely in touch with the problems and activities of the Empire to-day. Education, citizenship, and economic and industrial difficulties will all be prominent features of the programme.

There is every reason, therefore, to believe that the meeting will be of unique interest and importance. Whether it will be an equal success in point of numbers in attendance is less certain. The amount of interest shown locally in the proceedings cannot at the time of writing be said to have come up to expectations. This comparative lack of enthusiasm is not, however, surprising in a town of so many and diverse distractions. The NO. 26OI, VOL. IO4] number of applications for associateship and membership is at present much smaller than anticipated, but in the opinion of those competent to judge the eleventh hour will bring a marked improvement in this direction.

One of the greatest problems which the local executive committee has had to face has been that of finding accommodation for visitors. A popular seaside resort in September inevitably presents extraordinary difficulties in this respect. Great efforts have been made to deal with the situation, and considerable public spirit has been displayed by hotel-keepers and others in helping the committee in its task.

The local preparations for the meeting are well in hand. The work of adapting the Municipal College to the needs of the Association is practically complete, and better accommodation has probably never been provided.

\section{THE PROTECTION OF WILD BIRDS.}

THE Report of the Departmental Committee on the Protection of Wild Birds, which has just been issued, after a considerable delay due to war conditions, marks an important step towards the proper and efficient control of British bird-life, which has been subject to the varying and complicated regulations of a long series of legislative enactments. The report foreshadows unified and simplified lines of regulation which, if adopted in law, ought to make the protection of wild birds not only more practicable, but also more effective. Of the fresh suggestions made by the expert Departmental Committee, to which the thanks of all naturalists are due, the most farreaching is that regarding the formation of a permanent Ornithological Advisory Committee, which would sit in London and not only advise the Central Authority on all ornithological questions, but also collect information and control investigations bearing upon the activities and status of wild birds. It is astounding to learn, though it is undoubtedly on a par with the official attitude towards science, that the Wild Birds Protection Acts have been administered without any expert ornithological assistance, except in the case of Scotland. Even there the matter of advice seems to have been, so to speak, behind the scenes, for there is no evidence of public acknowledgment of this highly technical information and advice.

Of many suggested improvements upon the old laws, mention can only be made of a few. All birds are recommended for protection during the breeding season, from May $\mathrm{r}$ to September $\mathrm{I}$, subject to the right of the owner or occupier, but even this exception is abolished in the case of scheduled birds, which, in Schedule A, including more than fifty species, are absolutely protected during the breeding season, and in Schedule B, including about twenty-seven species, are absolutely protected throughout the year. The unifying of the schedules for the protection of both birds and eggs is a vast improvement upon the present 